\title{
Pemetaan Keterlibatan Pemangku Kepentingan yang Berpengaruh dalam Pembangunan PLTN Pertama di Kalimantan Barat
}

\author{
Nurlaila $^{\star 1}$, Sufiana Solihat ${ }^{1}$
}

${ }^{1}$ Pusat kajian Sistem Energi Nuklir, BATAN, Jl. Kuningan Barat Mampang Prapatan, Jakarta Selatan, Indonesia

\begin{tabular}{l}
\hline INFORMASI ARTIKEL \\
\hline Riwayat Artikel: \\
Diterima: \\
09 Maret 2020 \\
Diterima dalam bentuk revisi: \\
04 Mei 2020 \\
Disetujui: \\
14 Juli 2020
\end{tabular}

Kata kunci:

IAEA

Kalimantan Barat

Pemangku Kepentingan

PLTN

\begin{abstract}
ABSTRAK
PEMETAAN KETERLIBATAN PEMANGKU KEPENTINGAN YANG BERPENGARUH DALAM PEMBANGUNAN PLTN PERTAMA DI KALIMANTAN BARAT. Berdasarkan pedoman IAEA Nuclear Series No. NG-G.31, negara pendatang baru dalam bidang PLTN perlu mempersiapkan 19 aspek infrastruktur. Hasil reviu IAEA menyatakan bahwa di Indonesia terdapat tiga infrastruktur yang masih belum siap. Salah satu aspek tersebut adalah kesiapan keterlibatan pemangku kepentingan. Makalah ini menampilkan pemetaan pemangku kepentingan di provinsi Kalimantan Barat dan keterlibatannya dalam rencana pembangunan PLTN di Indonesia. Fokus penelitian di Kalimantan Barat sesuai dengan lokasi rencana pembangunan PLTN. Tujuan makalah adalah memetakan pihak pemangku kepentingan mana saja yang memiliki pengaruh terkuat dan tingkat keinginan tertinggi dalam pembangunan PLTN, khususnya pada tahap pengambilan keputusan dibangunnya PLTN (tahap pertama). Metode yang digunakan adalah studi literatur terkait dasar-dasar penentuan pihak yang menjadi pemangku kepentingan beserta cara analisisnya, wawancara dan diskusi dengan para narasumber yang sesuai dan ahli di bidangnya juga diskusi langsung dengan para responden, serta pembagian kuisioner kepada para responden. Selanjutnya hasil kuisioner diolah dnegan menggunakan spreadsheet dan ditampilkan dalam grafik menggunakan matriks Mendelow. Hasil evaluasi dan analisis sementara menunjukkan bahwa secara umum para pemangku kepentingan di Kalimantan Barat mempunyai pengaruh kuat dan keinginan tinggi terhadap rencana pembangunan PLTN di wilayahnya, kecuali LSM anti nuklir.
\end{abstract}

\begin{abstract}
MAPPING OF STAKEHOLDERS INVOLVEMENT INFLUENCING IN THE DEVELOPMENT OF THE FIRST NPP IN KALIMANTAN BARAT. Based on the IAEA guidelines Nuclear Series No. NG-G.31, the newcomer countries in the field of NPP need to prepare 19 aspects of infrastructure. The IAEA review results state that in Indonesia there are three infrastructures that are still not ready. One aspect is the readiness of stakeholder involvement. This paper presents a stakeholder mapping in the province of West Kalimantan and its involvement in the development plan of the NPP in Indonesia. The focus of the research in West Kalimantan is in accordance with the location of the NPP development plan. The purpose of this paper is mapping stakeholders which have the strongest power and the highest level of interest in the development of a nuclear power plant, especially at the decision-making stage for the NPP development (the first phase). The methods used are a literature study related to the basics of determining the parties to be stakeholders as well as how to analyze it, interviews and discussions with appropriate speakers and experts in their fields as well as direct discussions with respondents, and distribution of questionnaires to respondents. Then the results of the questionnaire were processed using a spreadsheet and displayed in a graph using the Mendelow matrix. The results of the interim evaluation and analysis showed that in general the stakeholders in West Kalimantan had a strong power and a high interest for the planned development of nuclear power plants in their region, except for anti-nuclear NGOs.
\end{abstract}

Keywords: IAEA, West Kalimantan, Stakeholders, NPP

(C) 2020 Jurnal Pengembangan Energi Nuklir. All rights reserved

\section{PENDAHULUAN}

Terkait dengan rencana pembangunan Pembangkit Listrik Tenaga Nuklir (PLTN) di Indonesia, Badan Atom Internasional (IAEA) telah memberikan pedoman IAEA Nuclear Series No. NG-G.31 yang berjudul "Milestone in Development of a National Infrastructures

*Penulis korespondensi.

E-mail: alialrun@batan.go.id for Nuclear Power" bagi suatu negara pendatang baru di bidang PLTN untuk dapat dijadikan acuan. Dalam pedoman tersebut dijelaskan bahwa program pembangunan PLTN terdiri atas 3 tahap, dan di akhir setiap tahapan tersebut ditandai dengan suatu milestone [1]. Adapun tahapan-tahapan tersebut diantaranya diawali dengan tahap 
Consider (pertimbangan) mengenai pengembangan tenaga nuklir di suatu negara, yang ditandai dengan penetapan keputusan secara resmi untuk dikembangkannya tenaga nuklir di negara tersebut. Setelah ditetapkannya keputusan pembangunan PLTN secara resmi, tahap selanjutnya yaitu Prepare (persiapan) mengenai hal-hal apa saja menyangkut pembangunan yang ditandai dengan ditetapkannya kontrak dengan vendor terkait yang akan dilibatkan dalam proses pembangunan PLTN. Tahap terakhir yaitu Construct (pembangunan) PLTN hingga siap dilakukan komisioning/dioperasikan untuk pertama kalinya.

Di dalam panduan IAEA tersebut juga disebutkan ada 19 (sembilan belas) infrastruktur yang harus dipersiapkan suatu negara terkait program PLTN (Gambar 1) [1,2]. Kesembilanbelas infrastruktur ini masih dalam tahap pertimbangan, yakni pada fase 1 .

Berdasarkan hasil reviu yang telah dilakukan oleh tim ahli dari IAEA pada tahun 2010 terhadap kesiapan Indonesia mengenai 19 jenis infrastruktur ini, ada 3 infrastruktur yang masih belum tersedia (perlu disiapkan) yaitu posisi nasional (national position), managemen, dan pemangku kepentingan (stakeholder involvement), sedangkan infrastruktur yang lain dinilai sudah siap.

Di Indonesia, tahap pertama (pertimbangan/consideration) umumnya dilakukan oleh institusi pemerintah (BATAN, Kemenristekdikti, dan Kementerian ESDM). BATAN ditugaskan secara khusus untuk mendukung secara teknis semua program ini. Kajian persiapan pembangunan PLTN di Indonesia sebenarnya sudah dilaksanakan sejak dulu. Akan tetapi, hingga saat ini PLTN belum benar-benar dibangun di Indonesia. Diantara jenis infrastruktur yang masih belum siap tersebut, 'pemangku kepentingan' merupakan hal yang sering kali kurang mendapatkan perhatian. Upaya pengembangan PLTN di Indonesia yang selama ini dilakukan seringkali tidak memperhatikan pihak pemangku kepentingan mana saja yang sebenarnya memegang pengaruh paling penting dan memiliki tingkat keinginan tertinggi terkait pembangunan PLTN, sehingga menjadi kurang tepat sasaran dan tidak ada pihak yang merasa bertanggungjawab atau diberi kewenangan untuk itu. Hal ini bisa jadi menjadi faktor penting yang menyebabkan belum terbangunnya PLTN di Indonesia.

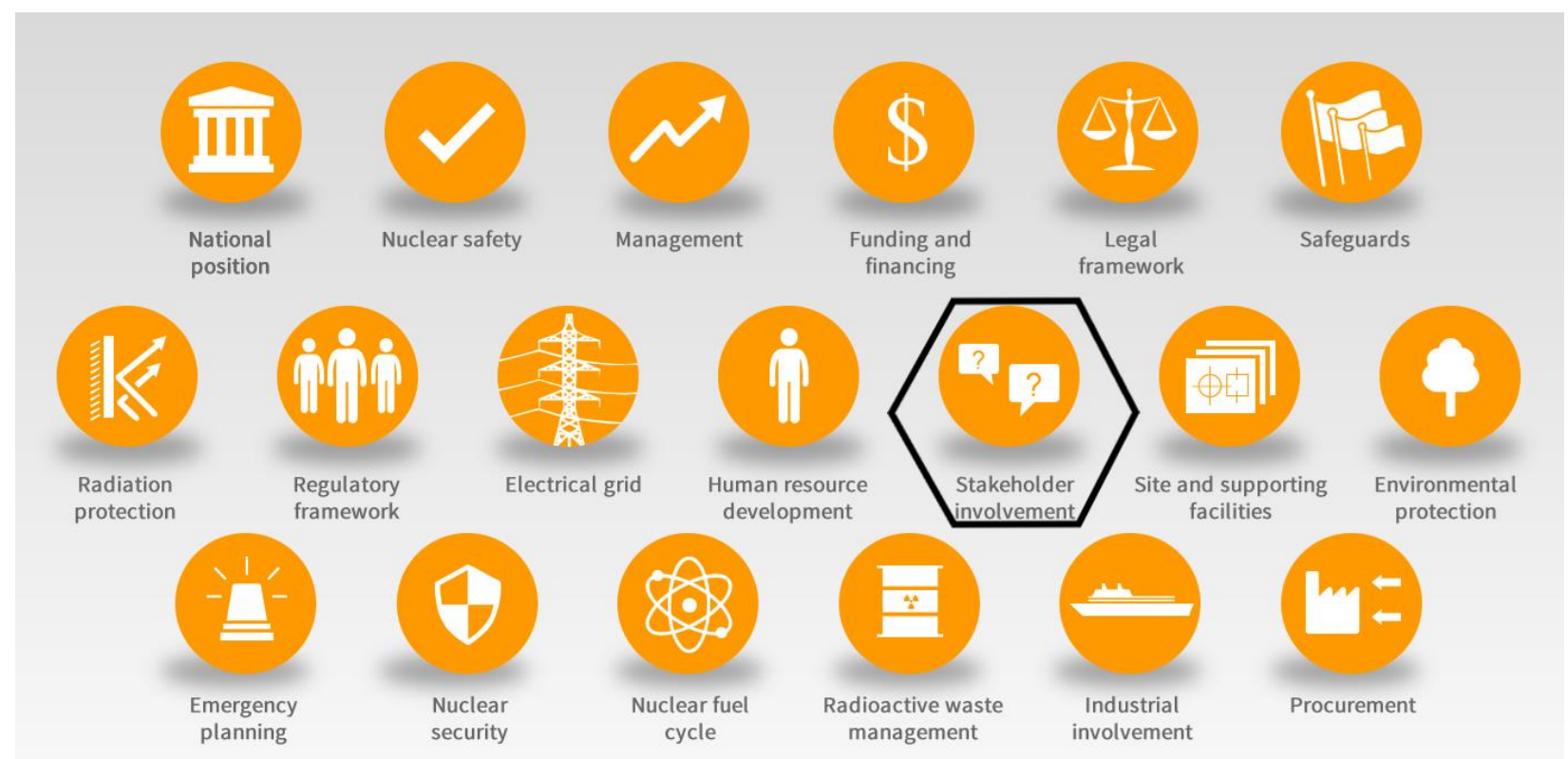

Gambar 1. Persiapan 19 Infrastruktur Pembangunan PLTN bagi Negara Pendatang Baru.

Saat ini, rencana pembangunan PLTN di Indonesia difokuskan di daerah Kalimantan Barat karena berdasarkan aspek geologi, kegempaan, dan aspek tapak lainnya, wilayah ini dianggap aman untuk dibangun PLTN, yang sekaligus akan menjadi PLTN pertama di Indonesia [3]. Penelitian ini bertujuan untuk memetakan pihak pemangku kepentingan mana saja yang memiliki pengaruh terkuat dan tingkat keinginan tertinggi dalam 
pembangunan PLTN, khususnya pada tahap pengambilan keputusan dibangunnya PLTN (tahap pertama). Dengan demikian pihak-pihak tersebut akan bertanggungjawab dalam upaya pengembangan PLTN di Indonesia mulai dari penetapan keputusan, penyusunan programprogram daerah yang mendukung terbangunnya PLTN, hingga sosialisasi masyarakat terkait manfaat PLTN dalam memenuhi kebutuhan energi listrik di Kalimantan Barat. Dalam hal ini, BATAN dapat melaksanakan tugas sebagai pemberi dukungan teknis terhadap pemangku kepentingan tersebut. Adapun langkahlangkah yang dilakukan dalam penelitian ini yaitu studi referensi, wawancara dan diskusi dengan para narasumber dan responden terkait, kuisioner, dan pengolahan hasil survei dengan Matriks Mendelow.

\section{TEORI PEMANGKU KEPENTINGAN}

Dalam tahapan pembangunan PLTN, peran keterlibatan pemangku kepentingan (stakeholder involvement, SHI) merupakan salah satu infrastruktur yang harus disiapkan dengan sempurna karena akan sangat menentukan apakah proyek ini berjalan sesuai dengan rencana atau tidak [4,5]. Pemangku kepentingan adalah sekelompok masyarakat, komunitas atau individu yang mempunyai hubungan/kepentingan terhadap suatu organisasi atau perusahaan atau dapat mempengaruhi/dipengaruhi oleh tujuan organisasi [6]. Setiap pemangku kepentingan pada setiap tahapan proyek perlu diidentifikasi secara detail. Secara umum para pemangku kepentingan pada proyek PLTN ditunjukkan pada Gambar 2. Pemain inti (key player) pemangku kepentingan adalah pemerintah, Nuclear Energy Program Implementing Organization (NEPIO), badan regulasi, dan pemilik/operator [7].

Bila dijabarkan secara umum maka pemangku kepentingan terdiri dari utilitas, operator, masyarakat, media (wartawan), NEPIO, pembuat opini, industri, pemerintah, pemilik, LSM dan pebisnis $[2,8,9]$.

Dalam prinsip-prinsip ini, perhatian khusus diberikan pada tujuan kebijakan pengaturan dan tata kelola. Lebih khusus lagi, tujuannya adalah untuk membuat kebijakan peraturan dan pemerintah lebih inklusif, demi memperkuat akuntabilitas pemerintah ketika mengembangkan, meninjau dan menegakkan peraturan dan untuk meningkatkan efektivitas dan efisiensi proses keterlibatan pemangku kepentingan dalam mengumpulkan masukan yang berharga untuk meningkatkan kerangka kerja peraturan negara [10]. Prinsip-prinsip ini juga dapat memberikan referensi yang bermanfaat untuk panduan praktis pemerintah dan inisiatif pengembangan kapasitas $[11,12,13]$.

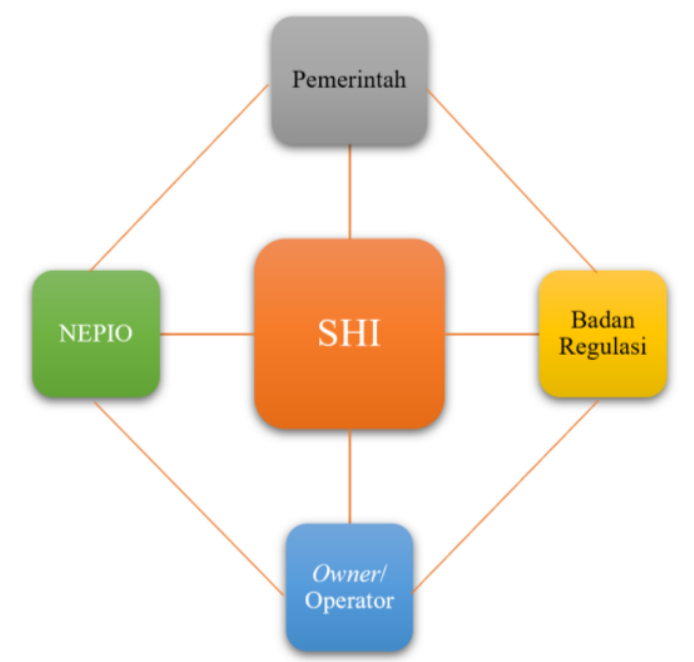

Gambar 2. Para Pemangku Kepentingan pada Proyek PLTN [2].

Pemangku kepentingan mempunyai peran strategis dalam suatu proyek mulai dari proses perencanaan hingga proyek diterima untuk dilaksanakan atau tidak [14]. Oleh karena itu semua pemangku kepentingan, baik internal maupun eksternal, perlu dilibatkan dan didorong untuk menjadi bagian dari perencanaan strategis agar lebih adaptif dan transformatif sesuai dengan keadaan sosial, budaya dan politik.

Pemangku kepentingan bukan hanya orang-orang yang mendukung rencana proyek kita, tetapi juga mereka yang sangat skeptis/menolaknya, dan bahkan mereka yang sebagian besar tidak peduli $[15,16]$. Menurut Miles, 2015, pemangku kepentingan dapat mencakup siapa saja dan semua orang yang memiliki beberapa tingkat kepentingan (termasuk kepentingan moral) dalam suatu masalah. Pemangku kepentingan dapat berupa individu, kelompok atau organisasi yang dapat mempengaruhi, dipengaruhi oleh, atau 
menganggap dirinya dipengaruhi oleh suatu program, proyek, atau kegiatan [17].

Peran utama dari setiap pemangku kepentingan dari proses pembangunan PLTN harus diidentifikasi untuk memetakan peran masing-masing di setiap proses, seperti kelompok penggerak/penggagas (driving group), pengambil keputusan politik (political decision makers), institusi pendukung secara teknis (technical support), institusi yang berkepentingan dan pembuat opini (interest and opinion), dan institusi sosial \& pendukung (social and institution support) [18,19]. Oleh karena itu, identifikasi setiap pemangku kepentingan dan peran utamanya harus dipetakan untuk setiap proses tahapan pembangunan PLTN [20], seperti ditunjukkan pada Tabel 1.

Tabel 1. Identifikasi Pemangku Kepentingan dan Peran Utamanya untuk Setiap Tahapan Pembangunan PLTN

\begin{tabular}{|c|c|c|c|c|}
\hline Driving Group & $\begin{array}{c}\text { Political Decision } \\
\text { Makers }\end{array}$ & Technical Support & $\begin{array}{l}\text { Interest and } \\
\text { Opinion }\end{array}$ & $\begin{array}{c}\text { Social and Institution } \\
\text { Support }\end{array}$ \\
\hline $\begin{array}{ll}- & \text { ESDM } \\
- & \text { BATAN } \\
- & \text { dll. }\end{array}$ & $\begin{array}{ll}\text { - } & \text { DPR } \\
\text { - } & \text { Pemerintah } \\
& \text { Daerah } \\
\text { - } & \text { Kementerian } \\
& \text { terkait } \\
\text { - } & \text { dll. }\end{array}$ & $\begin{array}{l}\text { - Universitas } \\
\text { - Peneliti } \\
\text { - Institusi bisnis } \\
\text { - dll }\end{array}$ & $\begin{array}{l}\text { - Asosiasi bisnis } \\
\text { - dll. }\end{array}$ & $\begin{array}{l}\text { - NGO } \\
\text { - Masyarakat lokal } \\
\text { - dll. }\end{array}$ \\
\hline
\end{tabular}

Keterlibatan pemangku kepentingan merupakan proses atau alat untuk mencapai keputusan yang memiliki informasi yang lebih baik dan diterima secara luas, sehingga keterlibatannya sangat penting untuk keberhasilan proyek karena berbagai alas an [21]. Menurut Eskerod et al., 2015 ada empat (4) alasan penting yang mendasarinya [22], yaitu:

a. proyek membutuhkan kontribusi (finansial dan non-finansial) dari pemangku kepentingan [23]

b. para pemangku kepentingan sering menetapkan kriteria untuk menilai keberhasilan proyek [24]

c. penolakan/hambatan dari pemangku kepentingan dapat menyebabkan berbagai risiko dan secara negatif mempengaruhi keberhasilan proyek, dan

d. proyek dapat memengaruhi para pemangku kepentingan baik secara negatif maupun positif

Para pemangku kepentingan sangat mempengaruhi keberhasilan proyek, khususnya untuk megaproyek, seperti PLTN dengan pemangku kepentingan yang heterogen dan kompleks. Oleh karena itu, manajemen proyek harus memahami pengaruh dan kepentingan pada seluruh tahapan implementasi proyek. Penyebab kegagalan umumnya terjadi pada tahap awal proyek, keterlibatan pemangku kepentingan yang efektif mungkin paling penting dalam fase awal ketika tujuan dan kriteria keberhasilan sedang ditentukan.

Menurut Mendelow, pengaruh dan kepentingan dari semua pemangku kepentingan dapat dipetakan melalui survei. Setiap pemangku kepentingan mempunyai ukuran nilai yang berbeda-beda. Mendelow mengukurnya berdasarkan nilai terendah hingga tinggi, seperti ditunjukkan pada Gambar 3, dimana kwadran pertama adalah keep satisfied, kwadran kedua adalah key players, kwadran ketiga adalah keep informed, dan kwadran keempat adalah minimum effort [25].

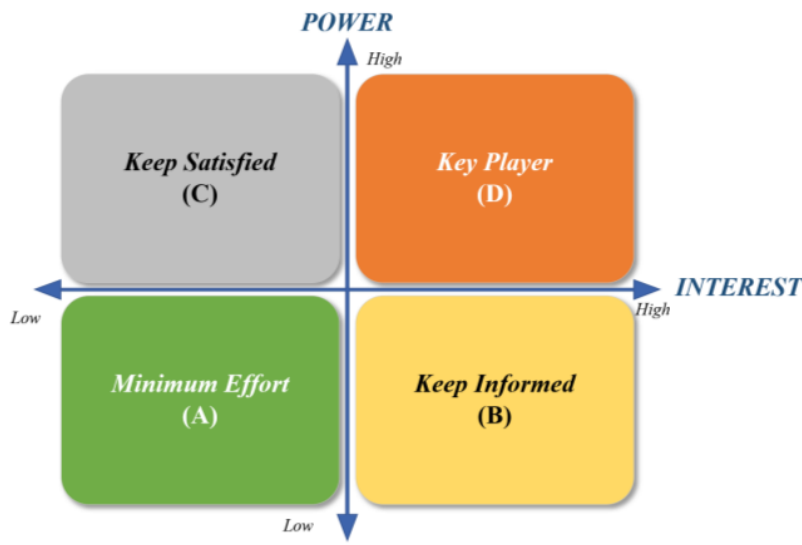

Gambar 3. Peta Mendelow.

Setiap pemangku kepentingan diharapkan memiliki potensi untuk memainkan peran penting dalam mempromosikan pemanfaatan PLTN sebagai salah satu energi bersih. Tetapi berbagai kepentingan mungkin akan timbul dari kelompok/individu terhadap pemanfaatan PLTN, yaitu posisi mendukung 
secara aktif, posisi netral, bahkan posisi menolak. Menurut John Griffiths ada lima (5) karakteristik yang mungkin ditunjukkan oleh pemangku kepentingan di posisi yang berbeda pada spektrum keterlibatan pemangku kepentingan, seperti ditunjukkan pada Tabel 2.

Tabel 2. Karakteristik Spektrum dari Pemangku Kepentingan [26]

\begin{tabular}{|c|c|c|c|c|}
\hline Resistor & \multicolumn{3}{|c|}{ Spektrum dari Pemangku Kepentingan } & Enabler \\
\hline Severe Resistor & $\begin{array}{l}\text { Moderate } \\
\text { resistor }\end{array}$ & Mild resistor/enabler & $\begin{array}{l}\text { Moderate } \\
\text { Enabler }\end{array}$ & $\begin{array}{l}\text { Proaktif } \\
\text { Enabler }\end{array}$ \\
\hline $\begin{array}{l}\text { - Tidak dapat atau } \\
\text { tidak mau } \\
\text { berubah }\end{array}$ & $\begin{array}{l}\text { - Tidak mungkin } \\
\text { berubah tanpa } \\
\text { bukti kuat }\end{array}$ & $\begin{array}{l}\text { - Mudah berubah dari } \\
\text { satu posisi ke posisi } \\
\text { lain }\end{array}$ & $\begin{array}{l}\text { - Terlibat sesuai } \\
\text { arah untuk } \\
\text { melakukannya }\end{array}$ & $\begin{array}{l}\text { - Meyakini manfaat } \\
\text { dari keterlibatan dan } \\
\text { mengambil peran } \\
\text { sebagai duta }\end{array}$ \\
\hline $\begin{array}{l}\text { - Tidak dapat } \\
\text { melihat manfaat }\end{array}$ & & $\begin{array}{l}\text { - Kurang kesadaran } \\
\text { akan manfaat } \\
\text { keterlibatannya }\end{array}$ & $\begin{array}{l}\text { - Sadar akan } \\
\text { manfaat } \\
\text { keterlibatannya } \\
\text { dan mengambil } \\
\text { tindakan }\end{array}$ & $\begin{array}{l}\text { - Sudah } \\
\text { mengidentifikasi } \\
\text { perannya secara } \\
\text { jelas dalam } \\
\text { keterlibatannya }\end{array}$ \\
\hline $\begin{array}{l}\text { - Posisi dapat } \\
\text { dipengaruhi oleh } \\
\text { kepentingan } \\
\text { pribadi }\end{array}$ & & & $\begin{array}{l}\text { - Memfasilitasi } \\
\text { akses pada } \\
\text { kegiatan tsb. }\end{array}$ & \\
\hline
\end{tabular}

\section{METODOLOGI}

Penelitian ini dilakukan di Pontianak, Provinsi Kalimantan Barat. Metode yang dilakukan dalam penelitian ini yaitu:

a. Studi referensi terkait dasar-dasar penentuan pihak yang menjadi pemangku kepentingan beserta cara analisisnya.

b. Wawancara dan diskusi dengan para narasumber yang sesuai dan ahli di bidangnya juga diskusi langsung dengan para responden untuk mendapatkan informasi tentang keterlibatan/pendapat mereka dalam pembangunan PLTN.

c. Pembagian kuisioner kepada para responden untuk mendapatkan data pengaruh dan keinginan mereka terhadap pembangunan PLTN dengan rincian sebagai berikut:

- Responden yang diberi kuisioner antara lain: Dinas Energi Sumber Daya Mineral (ESDM), Badan Perencanaan Pembangunan Daerah (Bappeda), Universitas, Perusahaan Listrik Negara (PLN), Tokoh Masyarakat, Lembaga Swadaya Masyarakat (LSM), dan lainlain. Dengan demikian, responden yang mengisi kuisioner adalah pihak yang termasuk dalam pemangku kepentingan, yang mana mereka akan menilai dirinya sendiri dan pihak pemangku kepentingan lain terkait pengaruh dan keinginan terhadap pembangunan PLTN di Indonesia.
- Bentuk kuisioner yang dibagikan kepada responden berisi penjelasan singkat mengenai program PLTN dan kaitannya terkait keterlibatan pemangku kepentingan, penjelasan pengisian kuisioner, serta tabel yang harus diisi oleh para responden.

- Di dalam tabel tersebut terdapat daftar pemangku kepentingan yang perlu dinilai oleh responden mengenai kekuatan pengaruh dan keinginannya terhadap pembangunan PLTN di Kalimantan Barat. Responden pun dapat menambahkan pihak lain yang tidak ada dalam daftar, yang menurut mereka penting untuk diperhitungkan tingkat pengaruh dan keinginannya terhadap PLTN.

- Rentang penilaian adalah 1 sampai 5, semakin tinggi nilainya maka kekuatan pengaruh dan/atau keinginannya terhadap pembangunan PLTN semakin kuat. Jika nilai kekuatan pengaruh dan/atau keinginannya $\geq 3$, maka dapat dikatakan tinggi. Tetapi jika nilainya kurang dari 3, maka kekuatan pengaruh dan/atau keinginannya dapat dikatakan rendah.

d. Rekapitulasi dan pengolahan data.

Setelah kuisioner diisi oleh para responden, tahap berikutnya yaitu rekapitulasi dan pengolahan data hasil kuisioner dengan menggunakan Ms. Excel.

e. Penampilan dalam matriks Mendelow. 
Setelah direkapitulasi, kemudian hasilnya ditampilkan dalam bentuk kurva yang dibagi kedalam 4 kuadran. Metode ini dikenal dengan Matriks Mendelow, dimana variabel $\mathrm{x}$ merupakan tingkat keinginan (interest) dan variabel y merupakan tingkat pengaruh (power). Tingkat kuat-lemahnya pengaruh dan tinggi-rendahnya keinginan pemangku kepentingan dalam pembangunan PLTN akan terlihat setelah rekapitulasi penilaian dimasukkan ke dalam kurva Matriks Mendelow.

\section{HASIL DAN PEMBAHASAN}

Telah dilakukan survei pengaruh pemangku kepentingan terhadap rencana pembangunan PLTN di wilayah provinsi Kalimantan Barat. Pada studi awal ini, survei hanya dilakukan terhadap responden di ibukota provinsi Kalimantan Barat, yaitu di kota Pontianak. Survei dilakukan dengan tatap muka dan mengisi kuisioner. Responden yang disasar adalah para pemangku kepentingan yang dapat mewakili secara umum masyarakat di Kalimantan Barat.

Jumlah responden yang disurvei sebanyak 59 orang terdiri dari pemerintah (Gubernur, Bupati, Dinas Energi dan Sumber Daya Mineral, Bappeda), DPRD, PLN, institusi pendidikan, media massa, tokoh agama, tokoh masyarakat/adat, Lembaga Swadaya Masyarakat (LSM) baik yang pro maupun anti PLTN, Kamar Dagang dan Industri Daerah (Kadinda), dan masyarakat lokal dimana rencana tapak PLTN akan dibangun.

Analisis terhadap para pemangku kepentingan akan lebih mudah dilakukan jika para pemangku kepentingan ini dikelompokkan dalam 5 kelompok, sehingga lebih jelas peran mereka dalam mensukseskan rencana pembangunan PLTN ini. Lima (5) kelompok tersebut, yaitu pembuat keputusan politik (political decision maker), kekuatan penggerak (driving force), pendukung keteknikan (technical support), kepentingan dan opini (interest \& opinion), dan pendukung sosial \& institusi (social \& institution support) sebagaimana telah dijelaskan pada Tabel 1.
Rekapitulasi dan pengolahan data hasil kuisioner (berdasarkan rerata setiap pemangku kepentingan) dituangkan dalam bentuk tabel untuk setiap kelompok pemangku kepentingan. Kelompok pembuat keputusan politik (political decision maker) terdiri dari Gubernur, Bupati dan DPRD di tingkat daerah. Surveyor menanyakan kepada sejumlah responden atas peran mereka dalam mendukung rencana pembangunan PLTN di wilayah yang mereka pimpin. Dari rekapitulasi hasil survei diperoleh data untuk kelompok pembuat keputusan politik seperti yang ditunjukkan pada Tabel 3. Survei dilakukan terhadap kelompok penggerak (driving force) diantaranya Bappeda, Dinas ESDM dan PT. PLN karena kelompok ini yang membuat perencanaan supply and demand energi di provinsi Kalimantan Barat yang akan diajukan ke kelompok pengambil keputusan politik. Kelompok penggerak ini merekomendasikan pemanfaatan PLTN sebagai salah satu alternatif pembangkit listrik selain yang sudah ada saat ini. Dari rekapitulasi hasil kuisioner yang disebar dan diisi oleh para responden, diperoleh nilai seperti yang ditunjukkan pada Tabel 4.

Surveyor juga menanyakan kepada responden atas peran kelompok pendukung keteknikan (technical support) yaitu institusi pendidikan. Bagaimanakah peran dan dukungan mereka terhadap rencana pembangunan PLTN di provinsi Kalimantan Barat. Responden menjawab dengan hasil seperti yang ditunjukkan pada Tabel 5 .

Responden juga ditanyai oleh surveyor tentang bagaimana kepentingan dan kekuatan dari kelompok kepentingan dan opini (interest \& opinion), seperti media massa dan Kadinda dapat mempengaruhi rencana pembangunan PLTN di Kalimantan Barat. Apakah kepentingan dan opini bersifat positif atau negatif terhadap rencana pembangunan PLTN ini. Hasil responden ditunjukkan pada Tabel 6.

Sementara untuk kelompok pendukung sosial dan institusi (social \& institution support), seperti tokoh agama, tokoh masyarakat, masyarakat lokal dan LSM ditanyakan juga peran dan pengaruh mereka terhadap rencana pembangunan PLTN di wilayahnya. Dari hasil survei yang dilakukan diperoleh rekapitulasi hasil survei seperti yang ditunjukkan Tabel 7. 
Tabel 3. Hasil Survei Kelompok Pembuat Keputusan Politik

\begin{tabular}{|c|c|c|c|}
\hline No. & Kelompok Pembuat Keputusan & Kepentingan & Kekuatan \\
\hline 1. & Gubernur & 4,73 & 4,84 \\
\hline 2. & Bupati & 4,51 & 4,54 \\
\hline 3. & DPRD & 4,07 & 4,16 \\
\hline \multicolumn{4}{|c|}{ Tabel 4. Hasil Survei Kelompok Penggerak } \\
\hline No. & Kelompok Penggerak & Kepentingan & Kekuatan \\
\hline 1. & Bappeda & 4,01 & 3,94 \\
\hline 2. & Dinas ESDM & 3,98 & 3,86 \\
\hline 3. & PT. PLN & 4,43 & 4,06 \\
\hline \multicolumn{4}{|c|}{ Tabel 5. Hasil Survei Kelompok Pendukung Keteknikan } \\
\hline No. & Kelompok Pendukung Keteknikan & Kepentingan & Kekuatan \\
\hline 1. & Institusi Pendidikan & 3,80 & 3,63 \\
\hline \multicolumn{4}{|c|}{ Tabel 6. Hasil Survei Kelompok Kepentingan dan Opini } \\
\hline No. & Kelompok Kepentingan dan Opini & Kepentingan & Kekuatan \\
\hline 1. & Kadinda & 3,70 & 3,40 \\
\hline 2. & Media massa & 3,25 & 3,42 \\
\hline \multicolumn{4}{|c|}{ Tabel 7. Hasil Survei Kelompok Pendukung Sosial dan Institusi } \\
\hline No. & Kelompok Sosial dan Institusi & Kepentingan & Kekuatan \\
\hline 1. & LSM Pro PLTN & 3,37 & 3,46 \\
\hline & LSM Anti PLTN & 2,79 & 2,89 \\
\hline 2. & Tokoh Agama & 3,07 & 3,53 \\
\hline 3. & Tokoh Masyarakat/Adat & 3,33 & 3,64 \\
\hline 4. & Masyarakat lokal & 3,59 & 3,45 \\
\hline
\end{tabular}

Selanjutnya dilakukan analisis terhadap hasil survei dengan menggunakan metode Mendelow, dimana dapat digambarkan bagaimana pengaruh dan keinginan para pemangku kepentingan terhadap rencana pembangunan PLTN di Kalimantan Barat (Gambar 4).

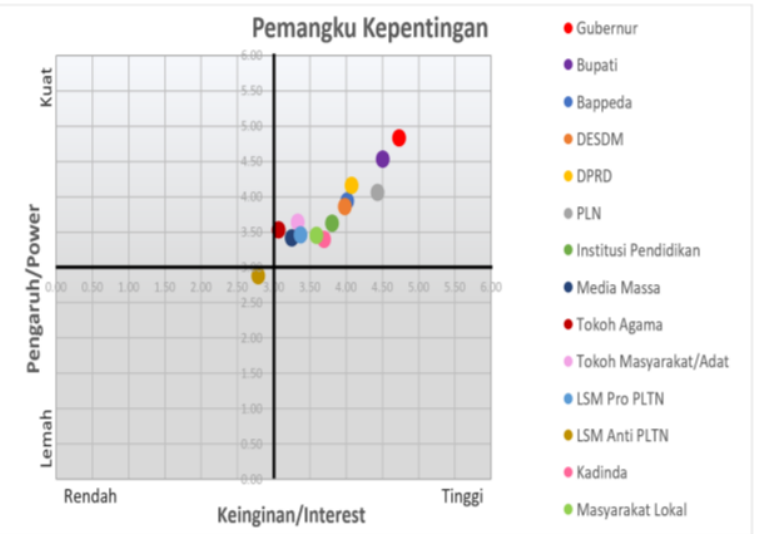

Gambar 4. Grafik Pemangku Kepentingan Menggunakan Metode Mendelow.

Mayoritas pemangku kepentingan mempunyai keinginan tinggi dan pengaruh kuat terhadap rencana pembangunan PLTN di Kalimantan Barat. Ada dua kelompok yang mempunyai keinginan rendah tetapi pengaruhnya juga rendah terhadap rencana pembangunan PLTN ini di daerahnya, satu kelompok pemangku kepentingan yang mempunyai pengaruh rendah tetapi keinginan kuat, dan ada satu pemangku kepentingan mempunyai pengaruh rendah dan keinginan juga rendah terhadap rencana pembangunan PLTN ini.

\section{a. Political Decision Maker (Pembuat Keputusan Politik) \\ Kekuatan politik sangat mempengaruhi} suatu keputusan dalam suatu rencana apapun di suatu wilayah. Kepala daerah dan DPRD merupakan kekuatan sentral dalam rencana pembangunan di wilayahnya. Hasil survei rencana pembangunan PLTN di Kalimantan Barat yang dilakukan terhadap responden di kota Pontianak, diperoleh data seperti yang ditunjukkan pada Tabel 3 dan Gambar 5.

Hasil survei dan analisis menggunakan metode Mendelow menunjukkan bahwa Gubernur, Bupati dan DPRD mempunyai pengaruh dan keinginan sangat kuat terhadap rencana pembangunan PLTN di wilayahnya. Dari ketiga pembuat keputusan politik ini, ternyata gubernur yang paling kuat pengaruh dan keinginannya terhadap rencana pembangunan PLTN ini, sedangkan yang paling rendah adalah DPRD. 


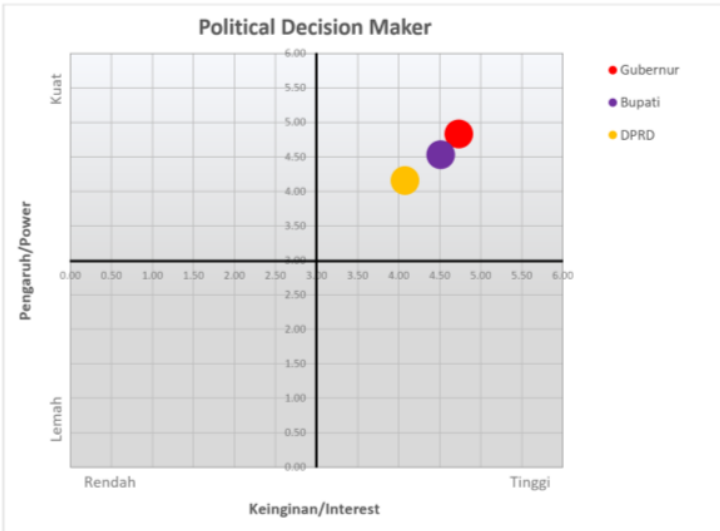

Gambar 5. Grafik Mendelow untuk Political Decision Maker (Pembuat Keputusan Politik).

\section{b. Driving Force (Kekuatan Penggerak)}

Dalam kolom kuisioner, ada 3 (tiga) kelompok kekuatan penggerak dalam rencana pembangunan PLTN di provinsi Kalimantan Barat, yaitu Bappeda, Dinas Energi dan Sumber Daya Mineral, dan PT. PLN. Bappeda berperan dan berfungsi untuk menyusun dan merencanakan kebutuhan energi listrik di daerahnya yang akan diajukan ke pemerintah pusat. Dinas ESDM bersama dengan PLN melakukan studi perencanaan kebutuhan energi listrik di masa yang akan datang di Kalimantan Barat. Hasil studi ini diajukan ke Bappeda agar dimasukkan dalam rencana pembangunan daerah.

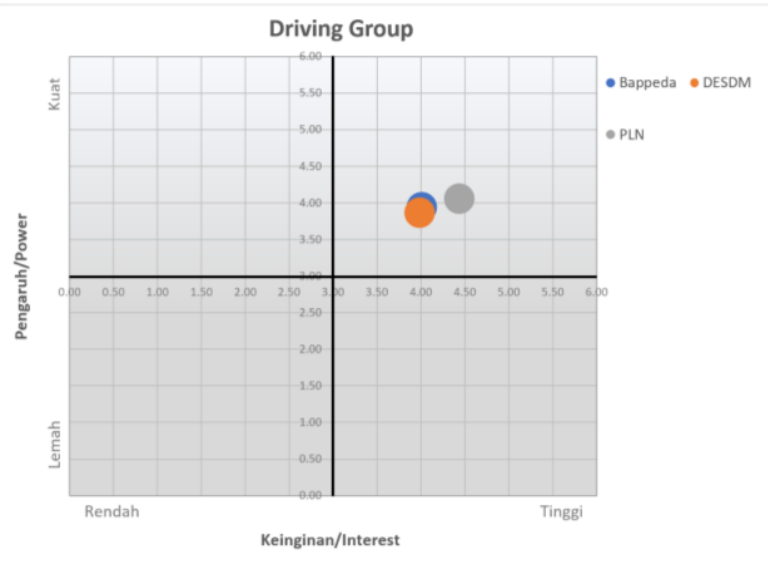

Gambar 6. Grafik Mendelow untuk Driving Group (Kelompok Penggerak).

Ketiga pemangku kepentingan ini sangat strategis fungsinya dalam menggerakkan suatu rencana pembangunan listrik di daerahnya. Bagaimana peran ketiga pemangku kepentingan ini dalam rencana pembangunan PLTN ditunjukkan pada Tabel 4 dan Gambar 6. Dari hasil analisis data yang dilakukan, diperoleh bahwa ketiga kelompok penggerak ini mempunyai pengaruh dan keinginan yang sangat kuat terhadap rencana pembangunan PLTN di Kalimantan. Dari Gambar 6 terlihat jelas bahwa PT. PLN merupakan institusi yang mempunyai pengaruh dan keinginan paling kuat mewujudkan rencana pembangunan PLTN di Kalimantan Barat, sedangkan Bappeda dan Dinas ESDM hasilnya hamper setara.

\section{c. Technical Support (Pendukung Keteknikan)}

Responden umumnya menyatakan bahwa pendukung keteknikan mempunyai pengaruh dan keinginan kuat terhadap rencana pembangunan PLTN di Kalimantan Barat dengan skor lebih dari 3.5, seperti ditunjukan pada Tabel 5 dan Gambar 7.

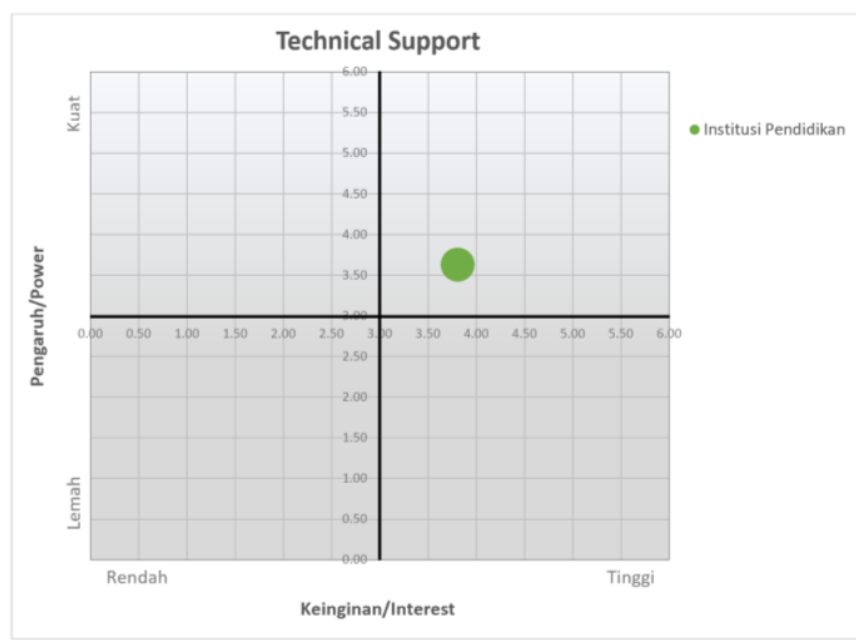

Gambar 7. Grafik Mendelow untuk Technical Support (Pendukung Keteknikan).

\section{d. Interest and Opinion (Kepentingan dan Opini)}

Pemangku kepentingan dari kelompok kepentingan and opini, diperoleh hasil dari responden seperti yang ditunjukkan pada Tabel 6 dan Gambar 8. Pemangku kepentingan dari media massa dan Kadinda mempunyai pengaruh dan keinginan yang cukup kuat terhadap rencana pembangunan PLTN di wilayahnya. Kadinda keinginannya lebih besar daripada media massa, sedangkan pengaruhnya hampir sama. 


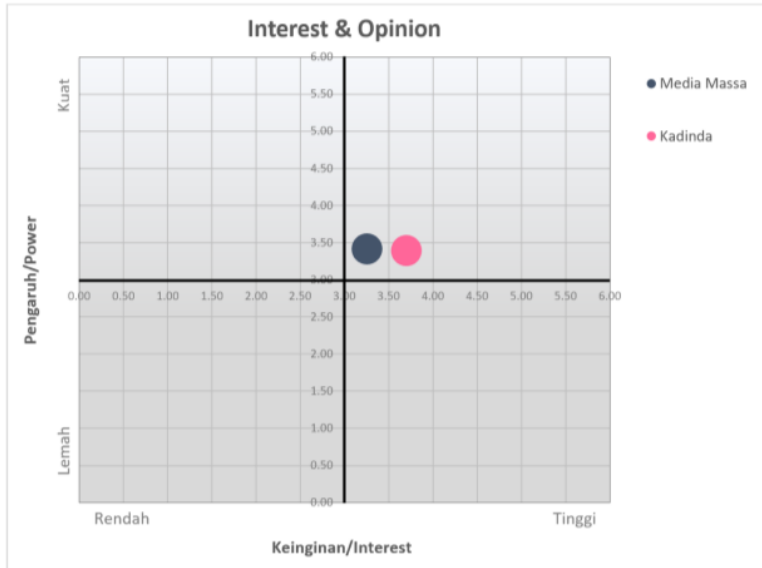

Gambar 8. Grafik Mendelow untuk Interest and Opinion (Kepentingan dan Opini).

e. Social and Institution Support (Pendukung Sosial dan Institusi)

Masyarakat pendukung sosial dan institusi terhadap rencana pembangunan PLTN di wilayah provinsi Kalimantan Barat, khususnya di kota Pontianak, seperti tokoh agama, tokoh masyarakat/adat, LSM pro nuklir, serta masyarakat lokal, dimana pengaruh dan keinginan mereka cukup kuat, kecuali pada LSM anti nuklir. Tokoh masyarakat mempunyai pengaruh lebih kuat (nilai lebih dari 3,5) tetapi keinginannya masih kurang dari 3,5. Sedangkan masyarakat lokal mempunyai keinginan cukup kuat (lebih dari 3,5), tetapi pengaruhnya masih kurang dari 3,5. Sementara tokoh agama mempunyai pengaruh cukup kuat (lebih dari 3,5), tapi keinginannya masih di nilai 3. Hal ini ditunjukan dari hasil evaluasi responden seperti yang ditunjukan pada Tabel 7 dan Gambar 9.

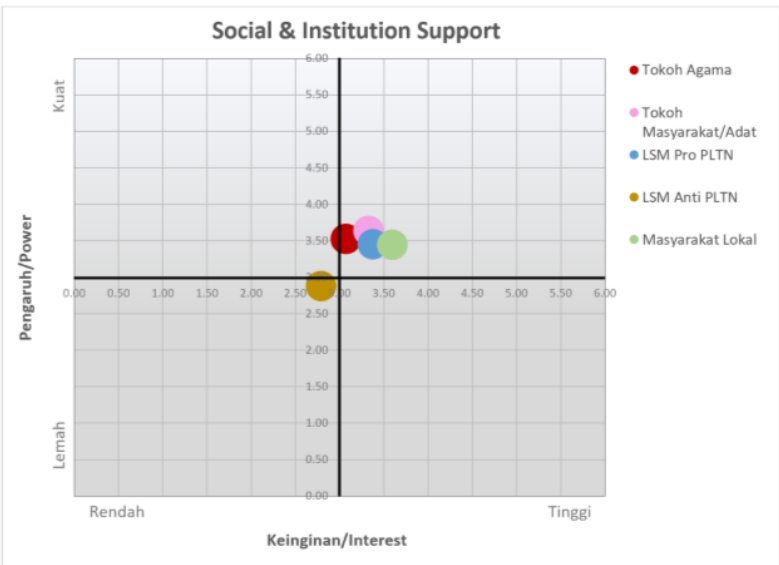

Gambar 9. Grafik Mendelow untuk Social and Institution Support (Pendukung Sosial dan Institusi).

\section{KESIMPULAN}

Hasil evaluasi dan analisis sementara yang telah dilakukan terhadap responden menunjukkan bahwa secara umum, para pemangku kepentingan di Kalimantan Barat mempunyai pengaruh kuat dan keinginan tinggi terhadap rencana pembangunan PLTN di wilayahnya, kecuali LSM anti nuklir (baik pengaruh maupun keinginan rendah berada di kuadran C pada grafik), sehingga pemetaan target sosialisasi pembangunan PLTN akan lebih mudah. Namun demikian hasil ini masih belum dapat memetakan secara ril bagaimana kekuatan dan keinginan yang sebenarnya dari masyarakat Kalimantan Barat, karena jumlah responden hanya 59. Untuk mendapatkan hasil yang lebih akurat, maka perlu dilakukan survei lanjutan dengan responden yang lebih variatif dengan melibatkan berbagai lembaga yang belum disurvei seperti kalangan tokoh masyarakat/adat, masyarakat lokal baik di tingkat provinsi hingga tingkat lokal.

\section{UCAPAN TERIMA KASIH}

Ucapan terima kasih disampaikan kepada Pusat Kajian Sistem Energi Nuklir (PKSEN) BATAN, penelitian ini didanai dari DIPA BATAN 2019. Penulis juga pengucapkan terima kasih kepada Drs. Sahala Maruli Lumbanraja atas segala kontribusinya sehingga makalah ini dapat terselesaikan.

\section{DAFTAR ACUAN}

[1] J. Haddad, "IAEA Approach and Support for Newcomers," Regional Workshop on Challenges and Lessons Learned to Support the Decision Making for NPP and Development, no. June. Manila, 2018.

[2] J. Haddad, "Stakeholders Involvement for a Nuclear Power Programme," Regional Workshop on Challenges and Lessons Learned to Support the Decision Making for NPP and Development, no. June. Manila, 2018.

[3] E. E. A., H. Susiati, and Sunarko, "Analisis Spasial Awal Lokasi Calon Tapak PLTN di Kalimantan Barat," in Seminar Nasional Infrastruktur Energi Nuklir 2019, 2019, pp. 173-179.

[4] A. Aapaoja, H. Haapasalo, and P. Söderström, "Early Stakeholder Involvement in the Project Definition Phase: Case Renovation," ISRN Ind. Eng., pp. 1-14, 2013.

[5] J. I. T. Buertey, D. Amofa, and F. Atsrim, 
"Stakeholder Management on Construction Projects: A Key Indicator for Project Success," Am. J. Civ. Eng., vol. 4, no. 4, pp. 117-126, 2016.

[6] T. Morphy, "Stakeholder Definition What is a Stakeholder?," 2020. [Online]. Available: https://www.stakeholdermap.com/stakeholderdefinition.html. [Accessed: 05-Jun-2020].

[7] A. S. Agar, M. J. Goodfellow, Y. M. Goh, and L. B. Newnes, "Stakeholder perspectives on the cost requirements of Small Modular Reactors," Prog. Nucl. Energy, vol. 112, no. December 2018, pp. 51-62, 2019.

[8] J. Mielke, H. Vermaßen, S. Ellenbeck, B. F. Milan, and C. Jaeger, "Stakeholder Involvement in Sustainability Science - A Critical View," Energy Res. Soc. Sci., vol. 17, pp. 71-81, 2016.

[9] M. Welp, A. de la Vega-leinert, S. Stoll-kleemann, and C. C. Jaeger, "Science-based Stakeholder Dialogues: Theories and Tools," Glob. Environ. Chang., vol. 16, pp. 170-181, 2006.

[10] C. Í. Aydin, "Nuclear Energy Debate in Turkey: Stakeholders, Policy Alternatives, and Governance Issues," Energy Policy, vol. 136, no. July 2019, pp. 1-17, 2020.

[11] Hariyadi, "Agenda-Setting Pembangunan PLTN dan Pencapaian Ketahanan Listrik (Studi di Jepara dan Pangkal Pinang)," J. Ekon. Kebijak. Publik, vol. 7, no. 2, pp. 127-142, 2016.

[12] A. Ceglarz, A. Beneking, S. Ellenbeck, and A. Battaglini, "Understanding the Role of Trust in Power Line Development Projects: Evidence from Two Case Studies in Norway," Energy Policy, vol. 110, no. March, pp. 570-580, 2017.

[13] N. Li, D. Brossard, D. A. Scheufele, and P. P. H. Wilson, "Policymakers and Stakeholders' Perceptions of Science-driven Nuclear Energy Policy," Nucl. Eng. Technol., vol. 50, no. 5, pp. 773-779, 2018.

[14] X. Lin, C. M. F. Ho, and G. Q. P. Shen, "Who Should Take The Responsibility? Stakeholders' Power Over Social Responsibility Issues in Construction Projects," J. Clean. Prod., vol. 154, pp. 318-329, 2017.

[15] P. M. Connor, C. J. Axon, D. Xenias, and N. Baltaozkan, "Sources of Risk and Uncertainty in UK Smart Grid Deployment: An Expert Stakeholder Analysis," Energy, vol. 161, pp. 1-9, 2018.

[16] P. Eskerod and T. Larsen, "Advancing Project Stakeholder Analysis by The Concept 'Shadows of The Context' 2 ," Int. J. Proj. Manag., vol. 36, no. 1, pp. 161-169, 2018.

[17] S. Miles, "Stakeholder Theory Classification: A Theoretical and Empirical Evaluation of Definitions," J. Bus. Ethics, vol. 142, no. 3, pp. 437-459, 2017.

[18] S. Bell, S. Morse, and R. A. Shah, "Understanding Stakeholder Participation in Research As Part of Sustainable Development," J. Environ. Manage., vol. 101, pp. 13-22, 2012.

[19] J. Gaede and I. H. Rowlands, "How ‘ Transformative' is Energy Storage? Insights from Stakeholder Perceptions in Ontario," Energy Res. Soc. Sci., vol. 44, no. February, pp. 268-277, 2018.

[20] P. Toivanen et al., "Finland' s Energy System for 2030 As Envisaged by Expert Stakeholders," Energy Strateg. Rev., vol. 18, no. November 2016, pp. 150-156, 2017.
[21] C. Wamsler, "Stakeholder Involvement in Strategic Adaptation Planning: Transdisciplinarity and $\mathrm{Co}^{-}$ production at Stake?,"Environ. Sci. Policy, vol. 75, no. February, pp. 148-157, 2017.

[22] P. Eskerod, "Project Stakeholder Management Past and Present," Proj. Manag. J., vol. 46, no. December 2015, pp. 6-14, 2016.

[23] S. W. Kidd, "Nuclear power e Economics and public acceptance," Energy Strateg. Rev., vol. 1, no. 4, pp. 277-281, 2013.

[24] A. Kosilov, "National Nuclear Programme Internal and External Stakeholders," Vienna, 2011.

[25] A. L. Mendelow, "Environmental Scanning--The Impact of the Stakeholder Concept," in International Conference on Information Systems (ICIS), 1981, pp. 407-418.

[26] J. Griffiths, H. Maggs, and E. George, "Stakeholder Involvement," Dalian, 2007. 